\title{
Kasten Terk Edilen Bir Farz Namazın Kaza Edilebileceğine Delil Getirilen Bir Hadis ve Değerlendirmesi
}

\author{
Hüseyin Kahraman \\ Prof. Dr., Bursa Uludağ Üniversitesi, ìlahiyat Fakültesi, Hadis Ana Bilim Dalı \\ Bursa/Türkiye \\ huskahraman@hotmail.com \\ http://orcid.org/0000-0002-1345-4429
}

\begin{abstract}
Öz: Bir Müslümanın uyku veya unutma sebebiyle vaktinde eda edemediği bir farz namazı daha sonra kaza edebileceği hatta bunun gerekliliği konusunda ulema arasında ittifak vardır. Nitekim Hz. Peygamber'in beyanına göre bu durumun başka bir kefareti yoktur. Bununla birlikte âlimler, bir kişinin kasten terk ettiği yani kılması gerektiğine inanmasına rağmen tembellik ve başka işlerle meşguliyet gibi sebeplere binaen vaktinde eda etmediği namazları kaza edip etmeyeceği konusunda ihtilaf etmişlerdir. Bu ihtilaf büyük oranda, namazın terki ile iman arasında kurulan alakaya göre şekillenmiş görünmektedir. Uyku ve unutmaya ilaveten kasten terkedilen namazların da kaza edilmesi gerektiğine inanan âlimlerin tamamı, bu görüşlerinin delili olarak belli bir hadise işaret etmektedir. Bu hadise göre Allah Rasûlü şöyle buyurmaktadır: "Biriniz uyku veya gaflet sebebiyle namazı terk ederse onu hatırladığı vakit kılsın. Zira Allah 'namazı, beni hatırlamak için kıl' buyurur". Makale, bu hadisin söz konusu görüşün delili olup olamayacağı konusuna yoğunlaşmaktadır. Bu bağlamda dinin diğer verilerinde namaza yapılan vurgular ve özellikle de hangi durumlarda terki için kaza öngörüldüğüne işaret edilmekte, bu bilgilerle söz konusu hadisin uyumu araştırılmaktadır.
\end{abstract}

Anahtar Kelimeler: Hadis, Namaz, Namazın Terki, Namazın Kazası, Uyku ve Unutma, Kasten Terk.

Geliş Tarihi/Received Date: 06.04.2020

Kabul Tarihi/Accepted Date: 09.12.2019

Araştırma Makalesi/Research Article

Atıf/Citation: Kahraman, Hüseyin. "Kasten Terkedilen Bir Farz Namazın Kaza Edilebileceğine Delil Getirilen Bir Hadis ve Değerlendirmesi”. Uludağ Üniversitesi İlahiyat Fakültesi Dergisi 29/2 (Aralık 2020), 631-658. 


\title{
A Hadith and Its Assessment Proves That Intentionally Abandoned Prayer Could Be Performed After Its Own Time
}

\begin{abstract}
There is an alliance among the scholars that a Muslim can perform the prayer later that he could not perform on time due to sleep or forget. As a matter of fact, according to the Prophet's statement, this situation has no other atonement. However, scholars disagreed about whether a person would perform later a prayer that he didn't perform it in time due deliberately to reasons such as laziness and preoccupation. This dispute appears to be largely shaped by the relevance between prayer and the faith. All of the scholars who believe that prayers that are deliberately abandoned in addition to sleep and forgetting should be perform later point to a certain hadith as evidence of these views. According to this hadith, the Messenger of Allah states: "If one of you leaves the prayer due to sleep or heedlessness, do it when remember. Because Allah says "pray for me to remember me." The article focuses on whether this hadith could be evidence for that view. In this context, the emphasis on prayer and especially in which cases performing later is anticipated for abandonment in religious sources and the compatibility of this hadith with these informations is investigated.
\end{abstract}

Keyword: Hadith, Prayer, To Abandon Prayer, To Perform Prayer After its Time, Sleep and Forget, To Abandone Deliberately.

\section{Giriş}

Namaz İslam'da üzerinde en çok durulan ibadettir. Nitekim salât kelimesi Türkçe'deki namaz manasiyla seksenden fazla âyette geçmektedir. ${ }^{1}$ Kurân'da başka bir ibadete bu sıklıkla atıfta bulunulmamıştır. Kur'ân'a ilaveten sünnette de namazla alakalı pek çok açıklama yapılmış, edasına engel olabilecek her türlü mâniaya çözümler sunulmuştur. Sözgelimi suya ulaşma imkânı olmadığı durumlarda teyemmüm yeterli görülmüş, yolculuk hallerinde kısaltılmasına ve (mezhebî tartışmalar bir tarafa bırakılacak olursa) birleştirilmesine müsaade edilmiş, hastalık durumunda oturarak hatta gerekirse yatarak kılınabileceği söylenmiş, savaş ortamında bile nasıl kılınacağı tarif edilmiştir. ${ }^{2}$

Din, edası için mümkün olan bütün kolaylıkları gösterdiği namaz konusunda, birkaç husus dişında mazeret kabul etmemektedir. Mazeret kabul edilen hususlar içinde de temel olarak "النوم" ve "النسيان" yani uyuma ve unutmaya işaret edi-

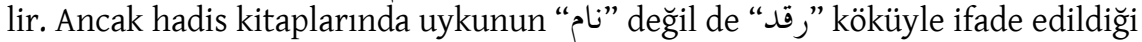
ve buna unutmak yerine gafletin eklendiği bir rivayet de vardır. Bu rivayete göre Allah Rasûlü şöyle buyurmuştur: "Biriniz uyku veya gaflet sebebiyle namazı terk

Muhammed Fuâd Abdülbâkī, el-Mu'cemü'l-müfehres li elfâzi'l-Kurâni'l-kerîm (Kahire: Matba'atü Dâri'l-Kütübi'l-Mısriyye, 1364/1945), 'slv', 412-413.

2 en-Nisâ 4/103. 
ederse onu hatırladı̆̆ı vakit kılsın. Zira Allah 'namazı, beni hatırlamak için kıl' buyurur."3

Namazların kazasının mümkün olup olmadığı ve eğer mümkünse bunun hangi durumlar için söz konusu edilebileceği ile ilgili tartışmalarda bazı ilim adamları gaflet ibaresinin yer aldığı bu rivayetlere özellikle işaret etmişlerdir. Buna göre uyuma ile unutmaya ilaveten kasten terk edilen yani farziyetine ve önemine inanılmasına rağmen başta tembellik olmak üzere çeşitli sebeplere binaen kılınmamış namazların da kaza edilmesi gerektiğini savunan ilim adamları bu hadisleri delil almışlardır.

Makalede namazların vaktinde ifa edilememesi hususunda uyuma ve unutma durumlarına ilaveten gafleti de mazeret addeden rivayetin öncelikle hadis nakil teknikleri açısından incelenmesine gayret edilecektir. Bu bağlamda söz konusu hadisin farklı müelliflerce nakledilen rivayetleri ile bunların sened ve metin yapılarına işaret edilecek ayrıca hem birbirleriyle hem de aynı konudan bahseden diğer hadislerle mukayesesine çalışılacaktır. Daha sonra da hadislerin muhteva ve delâleti tartışılacak, bu bağlamda özellikle gaflet kelimesi hakkında ileri sürülen farklı görüşlere temas edilecektir. Çeşitli âlimler tarafından bu kelime hakkında yapılan yorumların isabet payı, aynı konudan bahseden diğer hadisler ve özellikle de dinin namaz ve terki konusundaki temel verileriyle ilişki kurulmak suretiyle değerlendirilmeye çalışılacaktır. Dolayısıyla araştırılması hedeflenen temel mesele söz konusu rivayetlerin, kasten terk edilen namazların kaza edilmesi gerektiği yönündeki görüş için delil addedilmeye uygun olup olamadığıdır. Bu çerçevede makalede, namazların kazasının olup olmadığı tartışmasına girilmeyeceğini özellikle ifade etmemiz gerekir.

\section{Gafleti Namazın Terki Konusunda Mazeret Kabul Eden Rivayet}

Ahmed b. Hanbel, Müslim, İbn Mâce ve Nesâî tarafından nakledilen ${ }^{4}$ bu hadisin Müslim rivayeti şu şekildedir:

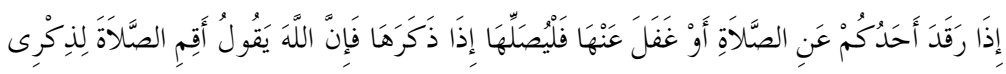

"Biriniz uyku veya gaflet sebebiyle namazını ihmal ederse hatırlayınca kılsın.

Zira Allahü Teâlâ 'namazı beni anmak için kıl' buyurur."

\footnotetext{
Hadisin Müslim rivayeti için bk. Müslim b. el-Haccâc Ebü'l-Hasen el-Kuşeyrî, el-Câmicu'ș-Ṣahị̣̂, thk. Muhammed Fuâd Abdülbâkī (Beyrut: Dâru İhyâi't-Türâsi'l-Arabî, 1954), "Mesâcid", 316.

4 Ebû Abdillâh Ahmed b. Muhammed b. Hanbel eş-Şeybânî, el-Müsned (isstanbul: Çağrı Yayınları, 1982), 3/184, 216; Müslim, "Mesâcid", 316; Ebû Abdillâh Muhammed b. Yezîd İbn Mâce el-Kazvînî, es-Sünen, thk. Muhammed Fuâd Abdülbâkī (Beyrut: Dâru'l-Fikr, ts.), "Mevâkịt", 10; Ebû Abdirrahmân Ahmed b. Şuayb en-Nesâî, es-Sünen, thk. Abdülfettâh Ebû Gudde (Haleb: Mektebetü'lMatbûâti'l-i̇slâmiyye, 1406/1986), "Mevâkịit”, 52.
} 
Diğer üç müellifin naklettiği hadisleri de aralarındaki küçük bazı farklara rağmen, aynı rivayet kapsamında değerlendirmek mümkün görünmektedir. Zira bütün bu rivayetler aynı muhtevaya sahip olup uyuma ve gaflet unsurlarına işaret etmektedir. Ayrıca bu dört rivayetin sahâbî ve tâbiî ravileri de aynıdır. Hatta Ahmed b. Hanbel ile Müslim'in üçüncü tabakadaki ravisi de aynı isim yani elMüsennâ b. Saîd'dir.

\subsection{Hadisin İsnad Yapısı}

Bu dört müellifin senedleri bir araya toplandığında şöyle bir rivayet şeması oluşur:

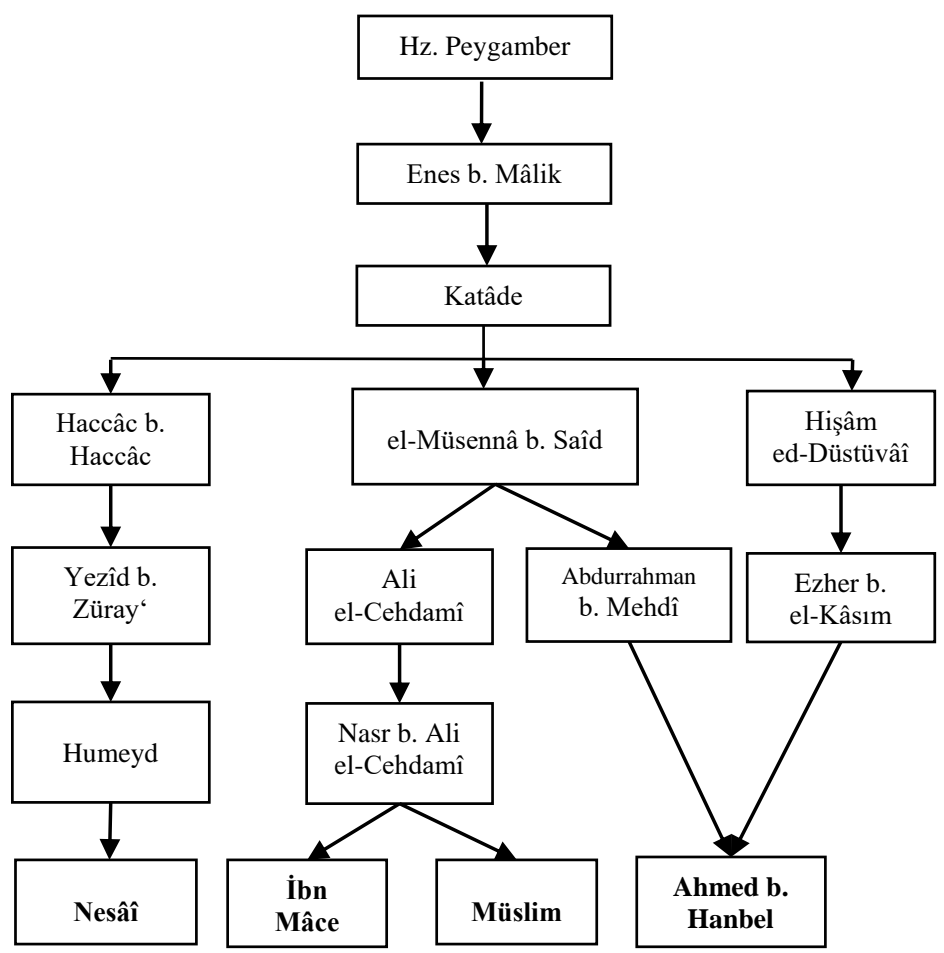

Tablo 1: Gafleti Namazın Terki Konusunda Mazeret Kabul Eden Hadisin İsnad Şeması

Bu şemadan da anlaşılacağı üzere hadisin sahâbî ve tâbiî ravileri rivayetlerinde tek kalmışlardır. Bununla birlikte Katâde b. Diâme (öl. 117/735), hakkındaki tedlis uyarıları bir tarafa münekkitlerin güvenilir bulduğu ve özellikle 
hâfıza cihetinden övdükleri bir ravidir. ${ }^{5}$ Hadisi Katâde'den nakleden raviler Haccâc b. Haccâc el-Bâhilî́, el-Müsennâ b. Saîd ${ }^{7}$ ve Hișam b. Ebî Abdillâh ${ }^{8}$ münekkitlerin güvenilir bulduğu ravilerdir. Sonraki tabakalarda yer alan raviler hakkında, Ahmed b. Hanbel'in hocası Ezher b. el-Kāsım istisna edilirse, görebildiğimiz kadarıyla ciddi bir eleştiri yoktur ve dolayısıyla hadisin sahih olduğu söylenebilir. Ezher hakkındaki eleştiriler de daha ziyade onun zabtı ile ilgilidir. ${ }^{9}$ Hadis bu tarîkten "hasen" olsa bile diğer tarîklerin desteği ile sahih li-gayrihi seviyesine yükselmiştir, denilebilir. Çünkü hadisin diğer tariklerinin sahih oldukları anlaşılmaktadır.

\subsection{Hadisin Metin Yapıs1}

Hadisin diğer üç müellif tarafından nakledilen metinlerinde, Müslim rivayetine göre bazı kelime farklılıkları, takdim-tehirler ve ilaveler görülür. Nitekim Nesâî rivayetinde ${ }^{10}$ metin şu şekildedir:

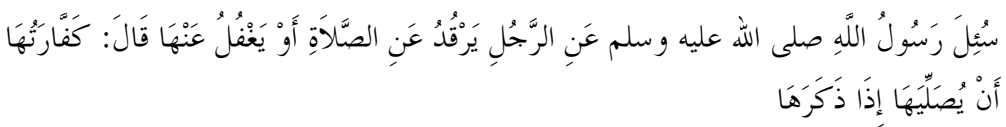

Görüldüğü üzere bu rivayette uyuma ve gaflet durumları Hz. Peygamber'in kendi ifadesi olmayıp O'na sorulan soru içinde yer alır. Ayrıca burada söz konusu

5 Nitekim Katâde'nin biyografisine yer veren hemen her müellif onun "sika” olduğunu söyledikten sonra mutlaka "tedlis yaptığına" da işaret etmektedir. Hatta bu bağlamda "bizzat duyduğu

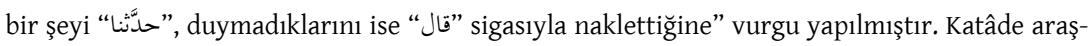
tırma konumuz olan hadisi de Enes'ten “" عن" ile nakletmektedir ki müdellis bir ravi için tercih edilen bir siga değildir; tedlîs işareti olarak algılanır. Tedlîs hakkında geniş bilgi için bk. Ebû Amr Osman b. Abdirrahmân İbnü's-Salâh eş-Şehrezûrî, 'Ulûmü'l-hadîs, thk. Nureddin Itr (Suriye: Dâru'l-Fikr, 1406/1986), 73-76. Fakat konuyla alakalı rivayeti nakleden tek sahabî, görebildiğimiz kadarıyla, Enes'tir. Ayrıca mesela Zührînnin de Enes'ten bu bağlamda rivayetleri vardır. Bu sebeple Katâde'nin hususen bu hadis hakkında tedlîs yapmadığı söylenebilir. Katâde b. Diâme hakkında geniş bilgi için bk. Ebû Abdillâh Muhammed b. Sa'd b. Menî‘ el-Bağdâdî, eț-Ṭabakātü'l-kübrâ, thk. Muhammed Abdülkādir Atâ (Beyrut: Dâru'l-Kütübi'l-îlmiyye, 1410/1990), 7/171-173; Ebü'lFazl Ahmed b. Ali b. Hacer el-Askalânî, Tehzî̉bü't-Tehzî̉ (Hindistan: Matbaatü Dâirati'l-Meârif, 13268), 8/351-356.

6 İbn Hacer, Tehżîbü't-Tehzîlb, 2/199-200.

7 İbn Hacer, Tehzîibü't-Tehzî̉, 10/34-35.

8 İbn Hacer, Tehzî́bü't-Tehzî́b, 10/196-197.

9 Ahmed b. Hanbel'in hocası Ezher b. el-Kāsım hakkında, özellikle zabtına yönelik bazı eleștiriler vardır. Nitekim bu ravi hakkında "sikadır" yönündeki değerlendirmeler kadar "hadisi yazılır ama delil alınmaz" ve "bazen hata yapar" şeklindeki eleştiriler de vardır (bk. İbn Hacer, Tehžîü'tTehzî̉, 1/205.

10 Nesâî, "Mevâkịit", 52. 
sebeplerle kılınmamıs namazların hatırlanınca kılınması kefaret olarak isimlendirilir. Yine bu rivayette, Müslim metninin sonunda yer alan "Zira Allah 'namazı beni anmak için kıl' buyurur." ifadesi de yoktur.

İbn Mâce rivayeti ${ }^{11}$ de, bazı küçük farkllıklarla birlikte, Nesâ̂i metnine benzemektedir:

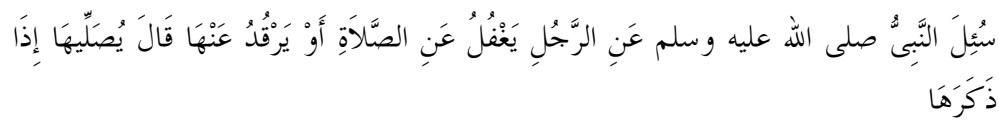

$\mathrm{Bu}$ rivayette de metin soru üzerine inşa edilmiştir. Ancak uyku ve gaflet ifadeleri takdim-tehir ile nakledilmiştir. Ayrıca Nesâî rivayetinde yer alan kefaret ifadesi burada yer almamaktadır.

Ahmed b. Hanbel'in "Hişâm $\leftarrow$ Katâde $\leftarrow$ Enes" tarîkinden naklettiğ $i^{12}$ rivayet ise uyku ve gaflet kelimelerinin yer değişmesi dışında daha ziyade İbn Mâce metnine benzemektedir:

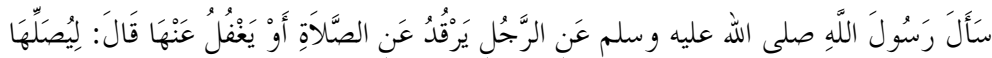

$$
\begin{aligned}
& \text { إِذَا ذَكَرَهَا }
\end{aligned}
$$

Buna karşın yine Ahmed b. Hanbel'in "Abdurrahman b. Mehdî $\leftarrow$ Müsennâ $\leftarrow$ Katâde $\leftarrow$ Enes" tarîkinde ${ }^{13}$ metin daha fazla ayrıntıya yer vermektedir:

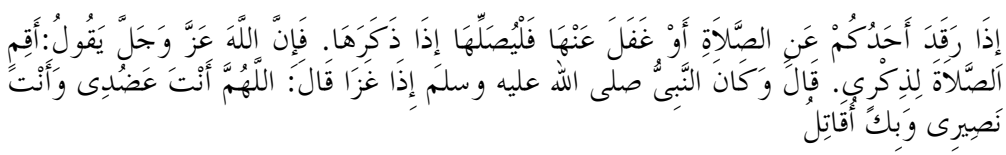

"Biriniz uyku veya gaflet sebebiyle namazı ihmal ederse hatırlayınca kılsın. Zira Allah 'Namazı beni anmak için kıl' buyurur. (Enes sözlerine devamla şöyle) dedi: Hz. Peygamber gazaya çıarken şöyle dua ederdi: 'Allahım! Desteğim ve yardımcım sensin. Ben de senin uğruna savaşıyorum."

Aralarında mana ile nakilden kaynaklanan çeşitli farklılıklar olsa da tarîklerin tamaminda ortak olan husus, uyku ve gaflet sebebiyle ihmal edilen namazların hatırlanınca kılınması gerektiğidir. Rivayetlerde uyku ile gaflet ifadeleri takdim-tehirle nakledilse bile ihmalin telafisi noktasında hep hatırlamaya vurgu yapilır. Hatırlamak lafzı hadisin delâletini tespit noktasında, bize göre önemlidir. Çünkü daha sonra tartışılacağı üzere hatırlama eyleminin uyku, unutma ve özellikle kasıtlı terk ile ilişkisinin kurulması gerekecektir.

İbn Mâce, "Mevâkịt", 10.

Ahmed b. Hanbel, el-Müsned, 3/216.

Ahmed b. Hanbel, el-Müsned, 3/184. 


\section{Hadisin Delâleti İle İlgili Görüşler}

Hadiste bir namazın daha sonra kaza edilebilmesine sebep olacak iki mazeretten bahsedilmektedir. Bunlardan birincisi olan "رقد" fiili esasen "gece veya gündüz, az ya da çok uyumak" manasına gelirken, bu hadiste de olduğu gibi "عن" harf-i ceri ile kullanıldı̆̆ında "oturmak, tehir etmek, gaflette olmak" gibi anlamlar da ifade edebilmektedir. Fakat bu bağlamda fiilin عن ile kullanımında ortaya çıkan tehir etme manasının daha ziyade kaçırmaktan dolayı geciktirme şeklinde olduğu görülür. ${ }^{14}$

Bununla birlikte görebildiğimiz kadarıyla kelimeyi hadisin bütünlüğü içinde bu manaya hamleden pek yok gibidir. Zira "رقد عن الصلاة" ifadesi Hz. Peygamber'in yaşadığı bir olayda, durumu tespit için bizzat O'na izafe edilir. Bu rivayete göre Allah Rasûlü ve beraberindekiler Hayber'den dönerken sabaha doğru mola verir. Bilal-i Habeşî, onları sabah namazına uyandırmak için nöbetçi kalır. Fakat yorgunluktan dolayı bir süre sonra o da uyur. Kafiledekilerin tamamı ancak güneş doğduktan sonra uyanabilirler. Bunun üzerine sahabîler sabah namazını k1lamadıkları için büyük bir endişeye kapılır... Hz. Peygamber onlara şöyle hitap eder:

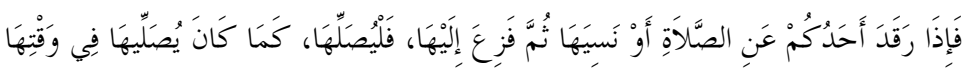

"Sizden biri uyumak veya unutmak suretiyle bir namazı eda edemez sonra da bundan dolayı endişeye kapılırsa bu namazı vaktinde kılıyormuş gibi kılsın". ${ }^{15}$

Bu rivayetten anlaşıldığı kadarıyla olayı anlatan sahâbî veya ondan sonra gelen ravilerden herhangi biri yaşanan durumu "رقد عن الصالة" ibaresiyle ifade etmekte beis görmemiştir. Kaldı ki aynı hadiseyi anlatan Ebû Cuhayfe rivayetinde ilgili kısım şu cümleyle ifade edilmiştir:

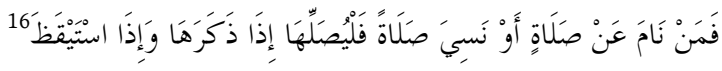

Dikkat edileceği üzere bu rivayette "رقد عن" yerine, aynı manaya delalet ede-

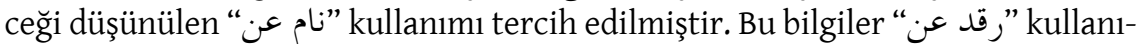
mının, nispeten geniş bir anlam çerçevesi bulunmasına ve "ihmali" çağrıştıracak

14 Ebü'l-Kāsım el-Huseyn b. Muhammed Râgìb el-İsfehânî, el-Müfredât fì garîbi'l-Kur'ân, thk. Safvân Adnan ed-Dâvûdî (Dımaşk: Dârü'l-Kalem, 1412), 362; Ahmed b. Muhammed el-Feyyûmî, elMiṣbâhu'l-münîr (Beyrut: el-Mektebetü'l-i̇lmiyye, ts.), 3/452; İbrahim Mustafa vd., el-Mu'cemu'lvasiț (Beyrut: Dâru'd-Da'vet, ts.), 1/364.

15 Ebû Abdillâh Mâlik b. Enes el-Asbahî, el-Muvațta', thk. Muhammed Mustafa el-A'zamî (Abu Dabi: Müessesetü Zâyed b. Sultan, 1425/2004), "Vukūtu's-salât", 11.

16 Ebû Bekr Abdullah b. Muhammed b. Ebî Şeybe el-Absî, el-Muṣannef, thk. Kemal Yusuf el-Hût (Riyad: Mektebetü'r-Rüşd, 1409, 1/411; 7/281; Ebü'l-Kāsım Süleyman b. Ahmed et-Taberânî, elMu'cemu'l-kebîr, thk. Hamdî b. Abdilmecid (Musul: Mektebetü'l-Ulûm ve'l-Hikem, 1404/1983), 22/107. 
mecazî vecihler ifade etmesine rağmen, en azından bu hadiste "uyumak, uyuyakalmak" manasına delâlet ettiğini göstermektedir.

Hadisin delâleti konusunda ihtilafa sebep olan, metnin ikinci temel vurgusu konumundaki "غفل" fiilidir. Nitekim tasavvuf, fikıh ve hadis ilimlerinde bir 1st1lâh haline gelmiş olan gaflet hakkında pek çok farklı tarif verilmiştir. Fakat bütün çeşitliliğine rağmen bu tarifleri şu iki başlık altında toplamak mümkündür:

1. Kasıtsız bir eylem olarak gaflet: Unutmak, farkına varmamak, dalgınlı, dalgınlıkla ihmal etmek, dikkatsizlik, dalgınlık veya dikkatsizlik eseri hata yapmak, yanılmak, aldanmak, fark etmemek, boş bulunmak, bir şeyin gerekliliği ortada iken bunu idrak edememek.

2. Kasıtlı bir eylem olarak gaflet: Terk, unutmadığı halde terk etmek, ihmal, zamanın boşa geçirilmesi, yeterince uyanık ve dikkatli davranılmadığı için insana arız olan yanılgı hali, yeterli ölçüde dikkat ve özen göstermediği için bir şeyi unutmak, nefsin kendi arzusuna uyması. ${ }^{17}$

Kelimenin anlam çerçevesi bu denli zengin olunca hadisin delâleti konusunda ihtilaf edilmesi kaçınılmaz olmuştur. Hadisin anlaşılması ile ilgili olarak ortaya atılan görüşleri şu başlıklar altında toplamak mümkündür:

\section{1. 'Gaflet, Kasten Terk Manasındadır' Görüşü}

Ebû Hanîfe ile İmam Şâfiî arasındaki ihtilaflara dair meseleleri işlediği elHilâfiyât isimli eserinde 109. başlı̆̆ı "Sonradan İslam'a dönen mürtedin, irtidât ettiği günlerde terk ettiği namazları kaza etmesi gerekir" konusuna ayıran Şâfiî hadis ve fikıh âlimi Beyhakî (öl. 458/1065) öncelikle Ebû Hanîfe'nin kaza etmez

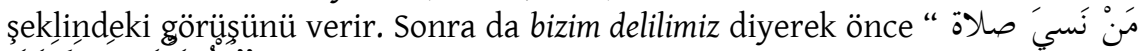

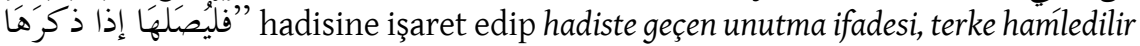
açıklamásında bulunur. Müellifin terk ifadesinden kasıt büyük ihtimâlle kasten

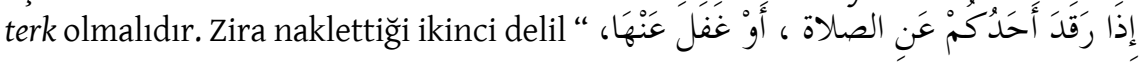

17 Nitekim Arap dil bilgini Ahmed el-Feyyûmî’nin (öl. 770/1368) şu tarifi, ulema arasındaki ihtilafın haksız olmadı̆̆ını gösterir gibidir: "Gaflet; bir şeyin insanın zihninden yok olması, onu hatırlamaması demektir. Bu kelime ihmal ve yüz çevirme sebebiyle bir şeyi terk eden kişi hakkında da kullanılır. Nitekim 'İnsanlar için hesap vakti yaklaştı. Hâlbuki onlar gaflet içinde yüz çevirmiş durumdalar' âyetinde de bu kullanım vardır”. bk. Feyyûmî, el-Miṣbâhụ'l-münîr, 2/449. Gaflet kelimesi hakkında geniş bilgi için bk. Râġb el-İsfehânî, el-Müfredât, 609; Ebü'l-Hasen Ali b. Muhammed es-Seyyid eş-Şerîf el-Cürcânî, et-Ta'rîfât, thk. Komisyon (Beyrut: Dârü'l-Kütübi'l-i̇lmiyye, 1403/1983), 67. Bu kelime hakkında ayrıca bk. Süleyman Uludağ, “Gaflet”, Türkiye Diyanet Vakfı İslâm Ansiklopedisi (İstanbul: TDV Yayınları, 1996), 13/283-284; H. Yunus Apaydın, “Gaflet”, Türkiye Diyanet Vakfi İslâm Ansiklopedisi (İstanbul: TDV Yayınlar1, 1996), 13/284-285; Selahaddin Polat, “Gaflet”, Türkiye Diyanet Vakfi İslâm Ansiklopedisi (İstanbul: TDV Yayınları, 1996), 13/285-286. 
"فَلْيُصَلِّها إذَا ذَكَرَها hadisidir. Beyhakîye göre irtidâd eden kişi Allah’ı zikirden gafil olmuş, hévâsına ittiba etmiştir. ${ }^{18}$

Mâlikî ilim adamı Şihâbüddin el-Karâfî (öl. 684/1285) öncelikle Ahmed b. Hanbel'in kasten terk eden kişi namazı kaza etmez; zira bu sebeple mürted olmuştur ${ }^{19}$ şeklindeki görüşünü aktarıp ona itiraz eder. Sonra da terk konusunda sebep ayrımı yapmaksızın yerine getirilmemiş her farz namazın kazası şarttır (vâcib) görüşünü savunup bizim delilimiz diyerek söz konusu hadise işaret eder. ${ }^{20}$ Bu yaklaşımından anlaşıldığına göre Karâfî, gaflet lafzını kasten veya özürsüz terk manasına hamletmektedir.

"Kişi uyuma ve unutma neticesinde kılamadığı namazı nasıl kaza eder"21 başlığı altında, içinde söz konusu hadisin de bulunduğu rivayetleri nakleden Hanefî âlim Aynî (öl. 855/1451) Hadisten Elde Edilecek Faydalar/Hükümler başlı̆̆1 altında sözü öncelikle mazeretsiz terk edilen namazlara getirir. Ona göre namazın kazası açısından bakıldığında uyumak ve unutmak gibi özürlere binaen terk etmek ile özürsüz terk etmek arasında fark yoktur. Özür sebebiyle namazı kaza etmek gerekiyorsa özürsüz terk durumunda kaza daha evladır. ${ }^{22}$

Hadislerde uyuma ve unutma halleri için söz konusu edilen kaza, kasten terk hususunda daha elzem ve gereklidir diyen Vehbe Zuhaylînnin (öl. 2015) delilleri arasında bu hadis de yer alır. ${ }^{23}$

Çağımız ilim adamlarından Nihat Yatkın da “...insan zayıf yaratılmıştır, bu yüzden her şeyde olduğu gibi namaz hususunda da ihmali söz konusu olabilir" dedikten ${ }^{24}$ sonra bahsi geçen bu rivayete işaret eder. Çeşitli verilerden hareketle

18 Ebû Bekr Ahmed b. el-Huseyn el-Beyhakî, el-Hilâfiyât beyne'l-imâmeyn eş-Şâficî ve Ebî Hanîfe ve așhâbih, thk. Mahmûd b. Abdülfettâh (Kahire: er-Ravda li'n-Neşr ve't-Tevzî‘, 1436/2015), 3/113.

19 Hanbelîlere göre namazın kasten terki küfürdür ve böyle bir şahsın katli vaciptir (bk. Ebû Muhammed Abdullah b. Ahmed b. Kudâme el-Makdisî, el-Mugnn̂̂ [Kahire: Mektebetü Kahire, 1388/1968], 2/330). Ahmed b. Hanbel'e göre namazlarını bu şekilde terk eden birinden namazlarını kılması istenmez ve beklenmez. bk. Abdullah b. Ahmed b. Hanbel, Mesẩilu Ahmed b. Hanbel, thk. Züheyr eş-Şâvîş (Beyrut: el-Mektebü'l-İslamî, 1401/1981), 55; Ebû Ya'lâ Muhammed b. elHuseyn el-Ferrâ, et-Ta'liḳu'l-kebîr fi'l-mesâ'ili'l-hilâfiye beyne'l-e'imme (thk. Muhammed b. Fahd, D1maşk: Dârü'n-Nevâdir, 1435/2014), 1/359.

20 Ebü'l-Abbâs Şihâbüddîn Ahmed b. İdrîs b. Abdirrahmân el-Karâfî, ez-Zahîra, thk. Muhammed Hacî (Beyrut: Dârü'l-Garb, 1994), 2/380.

21 Ebû Muhammed Bedrüddîn Mahmûd b. Ahmed el-Aynî, Nühabü'l-efkâr fî tenkîhi mebâni'l-ahbâr fî şerhi Me âni'l-Âsâr, thk. Ebû Temîm Yâsir b. İbrahim (Katar: Vüzeratü'l-Evkâf, 1429/2008), 7/149.

22 Aynî, Nühabü'l-efkâr, 7/160.

23 Vehbe b. Mustafa ez-Zuhaylî, et-Tefsîru'l-münîr fi'l-'akịde ve'ş-şerî‘a ve'l-menhec (Dımaşk: Dârü'lFikr, 1418), 16/190.

24 Nihat Yatkın, “Hz. Peygamber'in Sünnetinde Namazların Kazası”, EKEV Akademi Dergisi 3/1, 2001, 170. 
bu hadiste geçen gaflet kelimesinin bilerek terk etme manasına geldiğini savunan Yatkın, böyle kişilerin de namazlarını kaza etmesi gerektiği sonucuna ulaşır. ${ }^{25}$

Esasen bu yöndeki görüşleri, asıl tartışma konusu olan namazı kasten terkin imana etkisi ve bu konuda ortaya atılan görüşler bağlamında ele almak mümkündür. Malum olduğu üzere Hanbelîler böyle bir kişiyi tekfir ederken Hanefîler, Mâlikîler ve Şâfiîler kâfir değil günahkâr saymaktadır. Bu çerçevede Hanbelîlerin "kaza etmez" derken diğerlerinin "kaza etmelidir" görüşünü savunmaları, kendi içlerinde tutarlı olduklarının bir göstergesidir.

\section{2. 'Gaflet Unutmak Manasındadır' Görüşü}

Araştırma konumuz olan hadis, İmam Mâlik (öl. 179/795) tarafından gaflet yerine unutma yani نسى kelimesiyle nakledilmiştir:

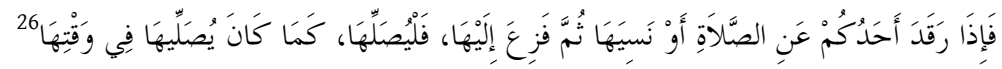

Buradan hareketle onun, gaflet kelimesini unutmak manasına hamlettiği söylenebilir.

Görebildiğimiz kadarıyla âlimlerin büyük çoğunluğu da gaflet ifadesini unutmak manasına hamletmişlerdir. Mesela Ebû Hanîfe (öl. 150/767), Ebû Yûsuf (öl. 182/798), Müzenî (öl. 264/868), Kerhî (öl. 340/951) gibi âlimler unutmak ve uyumak suretiyle bir namazı kılamayan kişinin onu kaza etmesi gerekir derken delil aldıkları hadisler arasında söz konusu hadis de vardır. ${ }^{27} \mathrm{Bu}$ da hadiste geçen gaflet ibaresini unutma anlamina hamlettiklerini gösterir.

Sözgelimi İbn Mâce (öl. 273/887) Namazı uyku ve unutma sebebiyle ihmal eden kişi başlığı altında ilk olarak metninde غقلد ve رقل geçen söz konusu hadisi nakleder. ${ }^{28}$ İbn Mâce'nin bu bab başlığı altında naklettiği ikinci ve üçüncü hadisler فاذا نسى أحدكى "dördüncü ve son hadis ise "من نسى صلاة فليصلها إذا ذكرها"

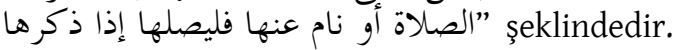

İbn Huzeyme (öl. 311/923) Hz. Peygamber'in uyumak veya unutmak suretiyle kllınamamış namazların iadesini emrettiğine dair delil babı cümlesiyle başlayan uzun bab başlı̆̆ı içinde kaza bağlamında uyanma ve hatırlamayı söz konusu eder. Müellifin bu başlık altında verdiği ilk rivayet, araştırma konumuz olan gaflet ve uyuma ile ilgili hadistir. ${ }^{29}$

\footnotetext{
25 Yatkın, “Hz. Peygamber'in Sünnetinde Namazların Kazası”, 171-172.

26 İmam Mâlik, “Vukūtu's-salât”, 11.

27 Mahmûd Muhammed Hattâb es-Sübkî, el-Menhelü'l-'ažbü'l-mevrûd şerhu Süneni'l-İmâm Ebî Dâvûd, thk. Emin Mahmûd Muhammed (Kahire: Matbaatü'l-İstikâme, 1351-1353), 4/24.

28 “باب من نام عن الصلاة أو نسيها”. İbn Mâce, “Mevâkît”, 10.

29 Ebû Bekr Muhammed b. İshâk b. Huzeyme en-Nîsâbûrî, eș-Ṣahîhh, thk. Muhammed Mustafa elA‘zamî (Beyrut: el-Mektebü’l-İslâmî, 1424/2003), 1/491.
} 
Ebû Avâne (öl. 316/928) söz konusu hadisi Uyumak ve unutmak suretiyle bir namazı kılamayan kişiden günahın kaldırılması cümlesiyle başlayan uzunca bir bab başlı̆̆ı altında verir. ${ }^{30}$

Aynı şekilde İbn Harrât (öl. 581/1185) da bu hadisi Uyumak veya unutmak suretiyle bir namazı kılamayan kişi için bu namazın vakti, hatırladı̆̆ı zamandır bab başlı̆̆ı altında nakleder. ${ }^{31}$

İbn Teymiyye'nin (öl. 728/1327) farz bir namazı vakti çıkana kadar kılmayan kişinin bunu kaza etmesi gerekir dedikten sonra getirdiği deliller arasında bu hadis de vardır. Daha sonra hadiste namazın terki uyuyan ve unutan kişiye tahsis edilmiştir... diyerek bazı açıklamalarda bulunur. ${ }^{32}$

Tefsir âlimi Hâzin (öl. 741/1340) "Namazı beni anmak için kıl” ayetinin tefsir

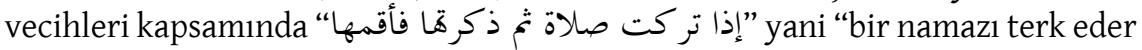

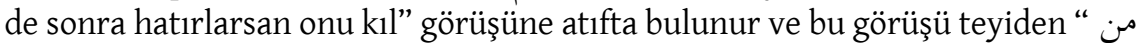
" hadisine işaret eder. Hemen sonra da "bir başka rivayette "şeklinde vârid olmuştur" der..$^{33}$ Buna göre Hâzin'in verdiği ikinci rivayetteki gaflet kelimesini, unutmak manasına hamlettiği düşünülebilir.

Kaza ancak bir vecibenin acziyet sebebiyle yerine getirilememesi durumunda söz konusu olur. (Böyle bir sebebe bağl) kaza, şarttır diyen Zeylaî (öl. 743/1343) buna delil olarak söz konusu hadisi zikreder. Malum olduğu üzere kasitta acziyet yoktur. Dolayısıyla Zeylaînnin bu hadiste geçen gaflet ibaresini unutmaya hamlettiği düşünülebilir. ${ }^{34}$

İbn Hacer el-Heytemî (öl. 974/1566) uyuma ve unutma gibi özürler nedeniyle kllınmamış bir namazın, borçtan kurtulmak adına hemen kılınması müstehab görülmüştür dedikten sonra ayrıca Sahihayn'da nakledilen bir haber de bunu emretmektedir bilgisini verir. Heytemî’nin bu bağlamda naklettiği haber “ إذا رقد أحد كم عن الصالاة

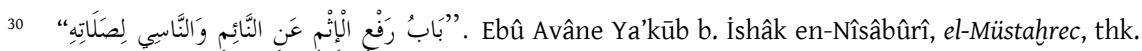
Eymen b. Ârif ed-Dimaşkî (Beyrut: Dârü'l-Ma'rife, 1419/1998), 1/562, 567.

31 Ebû Muhammed Abdülhak b. Abdirrahmân el-Endelusî (İbnü'l-Harrât), el-Ahkâmu'ş-şer'iyyeti'lkübrâ, thk. Hüseyin b. Ukkāşe (Riyad: Mektebetü'r-Rüşd, 1422/2001), 2/11.

32 Ebü'l-Abbâs Takıyyüddîn Ahmed b. Abdilhalîm el-Harrânî (İbn Teymiyye), Şerḥu'l-'Umde, thk. Hâlid b. Ali (Riyad: Dâru'l-Âsime, 1418/1997), 1/232.

33 Ebü'l-Hasen Alâüddîn Ali b. Muhammed el-Hâzin, Lübâbü't-te’vîlfìme’âni't-tenzîl, thk. Muhammed Ali Şahin (Beyrut: Dârü'l-Kütübi'l-i̇lmiyye, 1415), 3/202.

34 Fahruddîn Osman b. Ali ez-Zeylaî, Tebyînu'l-ḥakāàik şerhu Kenzi'd-dekāảik (Kahire: Dârü'l-Kütübi'lİslâmî, 1313), 1/185. 
"أو غفل عنها فليصلها إذا ذكرها hadisidir. ${ }^{35}$ "Heytemî’nin, bir namazı kazaya b1rakma konusunda sözünü ettiği mazeretler olan uyuma ve unutmaya "رقاؤند" ve "غفل fiillerini içeren hadisle işaret etmesi, gafleti unutmak manasına hamlettiğini gösterir.

Sَ Sَنْ نَسيَ صلاة “

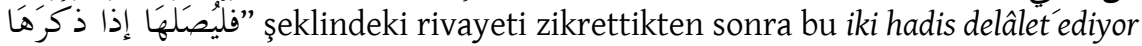
ki eğer bir kişi namazı uyumak veya unutmak suretiyle ihmal ederse, (uyanınca veya hatırlayınca) kılıması gerekir açıklamasında bulunur. Dolayısıyla müellifin gaflet ibaresini unutmak kelimesi ile karşıladığı söylenebilir. Nitekim o konunun akışı içinde namazı kasten terk edenlerin de onu kaza etmesi gerekir diyenlere itiraz ettiğini ama ciddi bir delillerinin olmadığını söyler. ${ }^{36}$

Sââtî̀nin bu hadisi zikrettiği babın başlığı da Kılmayı unutan kişi için namazın vakti hatırladı̆̆ı andır şeklindedir. ${ }^{37}$

Uyuduğu veya unuttuğu için bir namazı vakti çıkana kadar kılamayan kişinin bunu kaza etmesi gerektiği hususunda âlimlerin icmâl vardır diyen Şinkītî̀nin (öl. $1393 / 1974)$ buna getirdiği deliller arasında söz konusu hadis de yer alır. ${ }^{38}$

\section{3. 'Gaflet, Uyku Manasındadır' Görüşü}

Nesâî'nin Uyku sebebiyle namazı ihmal eden kişi başlığı altında naklettiği üç hadisten ilki budur. İkinci ve üçüncü hadisler ise Kusur, uyku değil uyanıklık hali için geçerlidir manasındadır. ${ }^{39}$

Kurtubî (öl. 656/1258)، hadisini

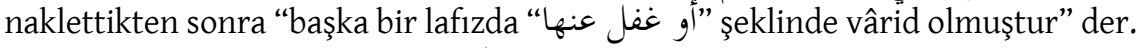
Kurtubî”nin bu açıklaması onun“"غفل" fiilini “" manasına hamlettiğini göstermektedir. Zira sözlerine devamla "bütün bu rivayetler uyuyanın da gafil olanın da bu namazı kaza etmesinin vacib olduğuna delâlet etmektedir" değerlendirmesinde bulunur. Hemen sonra da "وأما من ترك الصلاة عاملًا" diyerek namazı

\footnotetext{
35 Ebü'l-Abbâs, Ahmed b. Muhammed b. Hacer el-Heytemî, el-Minhâcu'l-kavîm (Beyrut: Dârü'l-Kütübi'l-ilmiyye, 1420/2000), 75.

36 Muhammed b. Ali eş-Şevkânî, Neylü'l-evțâr, thk. İsâmuddîn es-Sabâbitî (Mısır: Dâru'l-Hadîs, 1413/1993), 2/31.

37 Ahmed b. Abdirrahmân es-Sââtî, el-Fethü'r-rabbânî li-tertîbi'l-Müsnedil'-Imâm Aḥmed b. Hanbel eşŞeybânî (Beyrut: Dâru İhyâi't-Türâsi'l-Arabî, ts.), 2/301.

38 Muhammed el-Emîn b. Muhammed el-Muhtâr eş-Şinkîtî, Edvấcü'l-beyân fị îzâhhi'l-Kururāni bi'lKurrān (Beyrut: Dârü'l-Fikr, 1415), 3/456

39 “باب فيمن نام عن صلاة". Nesâî, “Mevâkịt”, 52.
} 
kasten terk etmenin hükmünü tartışır. Bu yaklaşımı da onun gafleti, kasıtlı bir eylem görmediğine işarettir. ${ }^{40}$

Tîbî (öl. 743/1342) "من نسي صلاة أو نام عنها، فكفارته أن يصليها إذا ذكرها "yani Unutmak veya uyumak suretiyle ihmal edilen namazın kefareti, hatırlaninca kılınmastdır hadisinin şerhinde نام fiili gaflet manasını da içerir ki söz konusu fiil burada uyku durumunda iken gaflet etti manasına gelir izahında bulunur. ${ }^{41}$ Mübârekpûrî (öl. 1414/1994) de Tîbî'nin bu açıklamasını aynen tekrarlar. ${ }^{42}$

Çağdaş ilim adamlarından İsyûbî̀ye göre hadiste "رقد" ile "غفل arasında bulunan " "و" harfinin, raviden kaynaklanan bir şüphe olması ihtimali de vardır. Böyle olması durumunda ravinin gafleti, uyku manasında kullandığı düşünülür. Müellife göre ikinci ihtimâl, ki bu daha açıktır, “و” harfinin atıf olmasıdır. Atıf olması durumunda umûmun husûsa atfı cinsinden bir mana ifade eder. ${ }^{43}$ Buna göre uyku da bir gaflet çeşididir.

\section{Değerlendirme}

Bütün bu verilerden anlaşıldığı kadarıyla gafletin uyku ve unutmak gibi istemsiz eylemler kadar kasten terk gibi istemli amellere de hamli mümkündür. Fakat kelimenin istemli davranışlara hamli dinin, namazın kasten terkini söz konusu etmesi ve bunun telafisini göstermesi gibi bir manaya gelecektir. Fakat bize göre, Müslüman toplum üzerinde ciddi etkiler bırakması açısından oldukça önemli olan böyle bir neticeye ulaşmadan önce, konuyla alakalı bütün rivayetlerin ve özellikle de namazın kasten terki konusunda dinin ortaya koyduğu tavrın incelenmesinde büyük fayda olacaktır.

\subsection{Hadisin Konuyla Alakalı Diğer Rivayetlerle İlişkisi}

Namazların kazasından bahseden hadislerin çok büyük bir kısmında buna imkân veren mazeretler görebildiğimiz kadarıla "النو م" ve "النسيان" yani uyumak ve unutmak eylemleriyle ya da sadece unutmak ile ilişkilendirilmiştir. Bu bağ-

40 Ebü'l-Abbâs Ahmed b. Ömer el-Kurtubî, el-Müfhim limâ eşkele min telhîṣi kitâbi Müslim, thk. Muhyiddin Dîb Misto (Dımaşk: Dâru İbn Kesîr, 1417/1996), 2/309.

$41 \quad$ "ضمن نام معنى غفل؛ أي غفل عنها في حال نومه، Şerefüddin el-Huseyn b. Abdillâh et-Tîbî, el-Kâşif‘an hakâa’iki's-sünen, thk. Abdülhamid Hindâvî (Riyad: Mektebetü Nizar Mustafa el-Bâz, 1417/1997), $3 / 888$.

42 Ebü'l-Hasen Ubeydullah b. Muhammed el-Mübârekpûrî, Mir'âtü'l-mefâtîh şerhu Mişkâti'l-meșâbîh (Hindistan: İdâretü'l-Buhûsü'l-İlmiyye, 1404/1984), 2/312.

43 Muhammed b. Ali el-İsyûbî el-Vellevî, Zehîratü'l-‘ukbâ fî şerhi'l-Müctebâ (Beyrut: Dârü'l-Me âric, 1416/1996), 7/601. 
lamda ilk iki ravisi Enes $\rightarrow$ Katâde olan hadisler özellikle dikkat çeker. Zira hatırlanacağ1 üzere uyumay1 "رقد" köküyle ifade edip buna "غفل ibaresini ekleyen rivayet de bu raviler aracılığı ile nakledilmiştir.

\subsection{1. 'Enes $\rightarrow$ Katâde' Tarîkiyle Gelen ve Gaflet Kelimesine Yer Vermeyen Rivayetler}

Namazın kazası konusunda uyuma ve unutma mazeretlerinden bir veya ikisine birden işaret eden ve Enes $\rightarrow$ Katâde tarîkinden gelen bu rivayetler ${ }^{44}$ bir araya toplandığında, ilk beş tabaka açısından aşağıdaki gibi bir isnad şeması ortaya çıkmaktadır.

Bu rivayetler içinde Saîd b. Ebî Arûbe (öl. 156/773) ${ }^{45}$, Şu'be (öl. 160/776) ${ }^{46}$, Haccâc b. Haccâc (öl. 131/748) ${ }^{47}$ ve Eyyûb Ebü'l-Alâ'dan (öl. ?) ${ }^{48}$ gelenlerde uyuma ve unutmanın her ikisine birden; Hemmâm b. Yahyâ ${ }^{49}$ ve Ebû Avâne'den ${ }^{50}$ gelenlerde ise sadece unutmaya işaret edilmiştir. İsnad şemasının da işaret ettiği üzere bu durum göstermektedir ki bir namazın ihmaline mazeret teşkil edecek hususlar bağlamında "نام" ve "نسى" kelimelerine işaret eden rivayetler, "رقدل" ve "غدام" ile ifade olunanlara oranla çok daha yaygındır.

${ }^{44}$ Bu rivayetler için bk. Ebû Abdillâh Abdullah b. Abdirrahmân ed-Dârimî, el-Müsned, thk. Hüseyn Selim Esed (Suud: Dâru'l-Muğnî, 1412/2000), "Salât", 26; İbn Ebî Şeybe, el-Musannef, 3/100, 243, 269; Ebû Abdillâh Muhammed b. İsmâîl el-Buhârî, el-Câmi'u'ṣ-Șaḥ̂hh, thk. Mustafa Dîb el-Buġā (Beyrut: Dâru İbni Kesîr, 1407/1987), "Mevâkịit”, 37; Ebû Dâvud Süleyman b. Eş‘as es-Sicistânî, esSünen (Beyrut: Dâru'l-Kütübi'l-Arabî, ts.), "Salât”, 11; Ebû Îsâ Muhammed b. Îsâ b. Sevre et-Tirmizî, es-Sünen, thk. Ahmed Muhammed Şakir (Beyrut: Dâru İhyai't-Türâsi'l-Arabî, ts.), "Salât", 131; ỉbn Mâce, "Mevâkịt", 10; Nesâî, "Mevâkịit", 52; Ebû Bekr Ahmed b. Amr el-Atekî el-Bezzâr, el-Müsned, thk. Âdil b. Sa‘d (Medine: Mektebetü'l-Ulûm ve'l-Hikem, 1988-2009), 13/398; Ebû Hâtim Muhammed b. Hibbân es-Büstî, eș-Ṣahîh, thk. Şuayb el-Arnaût (Beyrut: Müessesetü'rRisâle, 1414/1993), 4/423.

45 Bu rivayet için mesela bk. Dârimî, "Salât", 26.

46 Bu rivayet için mesela bk. Ahmed b. Hanbel, el-Müsned, 3/282.

47 Bezzâr, el-Müsned, 13/398.

48 Bu rivayet için bk. İbn Ebî Şeybe, el-Mușannef, 1/411; 7/281

49 Bu rivayet için mesela bk. Ahmed b. Hanbel, el-Müsned, 3/269; Buhârî, "Mevâkịt", 37; Ebû Dâvûd, "Salât", 11.

50 Bu rivayet için mesela bk. Ahmed b. Hanbel, el-Müsned, 3/243; Tirmizî, "Salât", 131; İbn Mâce, "Mevâkịit", 10; Nesâî, "Mevâkịit", 52. 


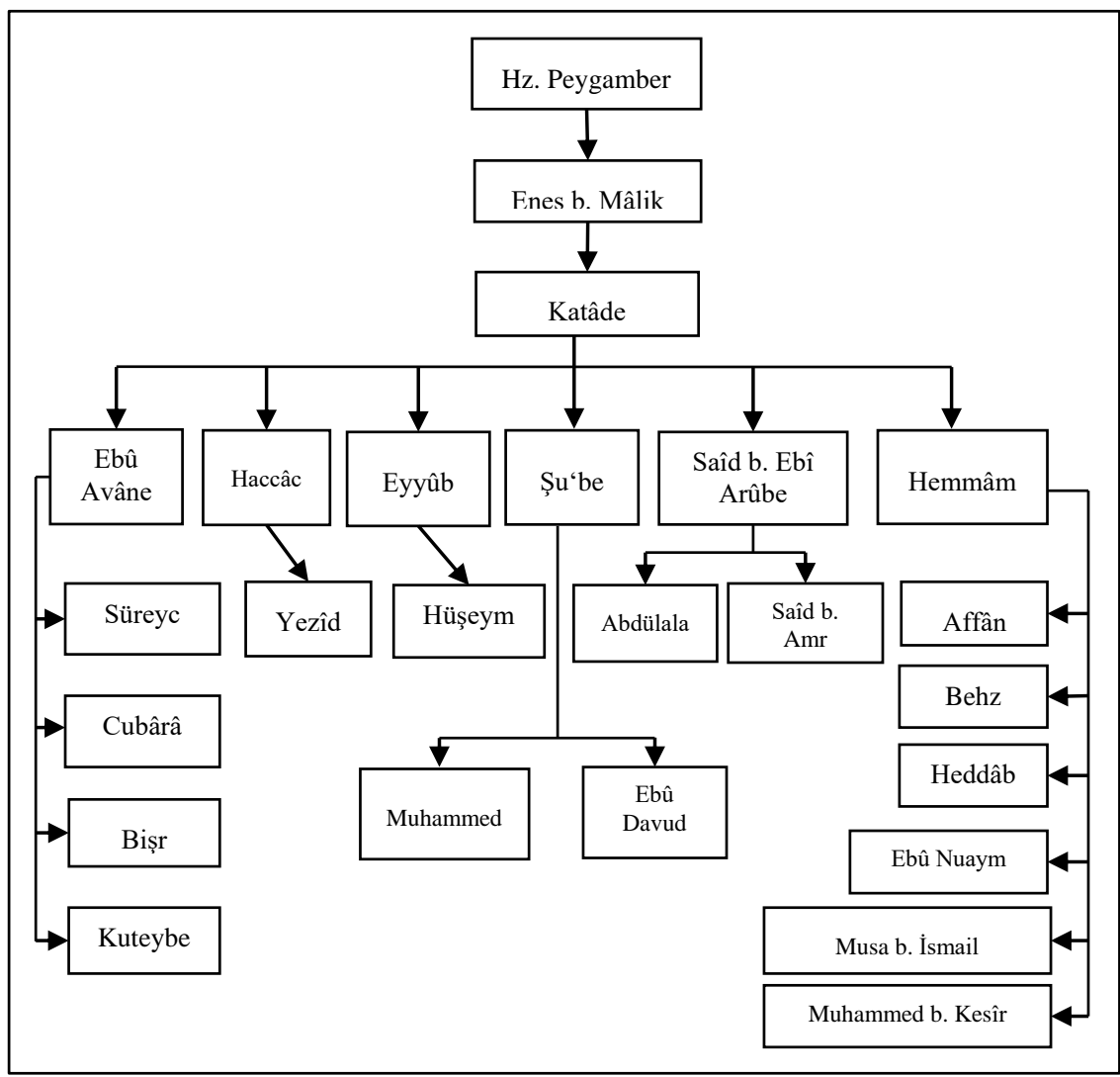

Tablo 2: ‘Enes $\rightarrow$ Katâde’ Tarîkiyle Gelen ve Gaflet Kelimesine Yer Vermeyen Rivayetler

Diğer taraftan bu iki gruptaki rivayetlerin tamamının Enes $\rightarrow$ Katâde tarîkiyle gelmiş olması evvel emirde, bunların hepsinin aynı hadise işaret ettiğini fakat mana ile nakilden dolayı böyle bir lafız farklılığına uğradığını akla getirmektedir. Zira gaflet lafzı, yukarıda geniş şekilde ortaya konduğu üzere, öncelikle unutmaya delâlet etmektedir. Eğer bu tespit doğruysa Katâde'nin aynı hadisi el-Müsennâ b. Saîd ve Hişam isimli öğrencilerine "رقد" ve "غفل lafızlarılyla; Ebû Avâne, Eyyûb Ebu'l-Alâ, Şube, Saîd b. Ebî Arûbe ve Hemmâm isimli öğrencilerine "نام" ve lafızlarıyla naklettiği düşünülebilir. Öyle görünüyor ki Katâde, Haccâc'a ise bir keresinde birinci, bir keresinde de ikinci gruptaki lafizlarla nakletmiştir. Zira Enes $\rightarrow$ Katâde $\rightarrow$ Haccâc b. Haccâc el-Bâhilî $\rightarrow$ Yezîd b. Züray tarîkiyle 


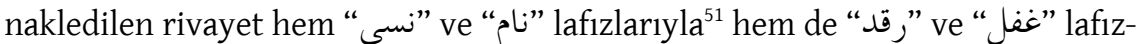
larılla aktarılmıştır. ${ }^{52}$

Bu bağlamda Katâde'nin ravileri içinde en güvenilir ve en hafiz olanı arand1ğında birinci sırada Saîd b. Ebî Arûbe'nin sayıldığına ${ }^{53}$ ve onun da hadisi "نسى" ve "نام" lafızlarıyla naklettiğine özellikle dikkat çekmek yerinde olacaktır.

Bizim mana ile rivayeti ön plana çıkaran bu değerlendirmemiz hakkında, daha önce şöyle bir itiraz ortaya atılmıştır:

“Ancak İmam Müslim'in mana ile rivayeti tecviz etmediği ve nebevi lafizlara daha çok itina gösterdiği de bilinen bir husustur. Dolayıslyla, 'غفل' fiilinin bizzat Rasulullah tarafindan kullanılmış olmasını... teyit etmekte, aksini ise zayıflatmaktadır. Çünkü konuyla ilgili kavlî hadislerin bir kısmında zaten 'غفل' fiili kullanılmıştır. Öyleyse bu hadislerdeki 'gaflet', 'unutma'dan başka bir manaya gelmeli ki, o da 'bilerek terk etme' olmalıdır, kanaatindeyiz". ${ }^{54}$

Buradaki değerlendirmelere pek de katılmadığımızı ifade etmemiz gerekir. Zira öncelikle gaflet ile unutmanın farklı manalara geldiğini savunabilmek için bu iki kelimenin aynı cümle içinde geçmesi ve ayrıca "g" harfiyle birbirlerine atfedilmesi gerekir. Hâlbuki görebildiğimiz kadarıyla hiçbir hadiste unutma ve gaflet kelimeleri bir arada geçmemektedir. Diğer taraftan İmam Müslim, lafız rivayetine verdiği önem kadar "bir hadisin bütün rivayetlerini peş peşe vermesi” ile de

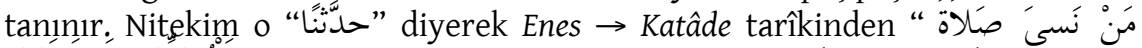

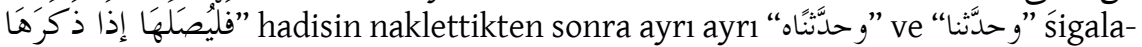
rıyla rivayetin çeşitli farklarla nakledilen lafızlarına işaret eder. Müslim'in bu

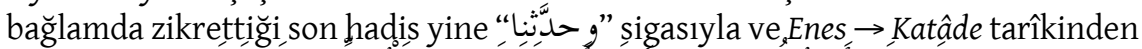

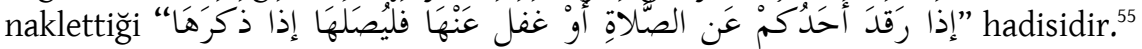
Sigaların başındaki “ " و" harfi, aynı hadisin değişiḱ rivayetlerine işaret içindir.

Aynı uygulama Beyhakî (öl. 458/1065) tarafından da sergilenmiştir. Nitekim o önce ...Katâde $\rightarrow$ el-Müsennâ... senedini sonra " $ح$ " işaretiyle tahvịle başvuraca-

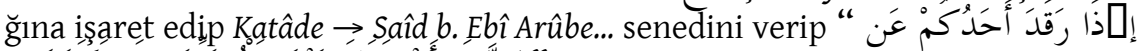

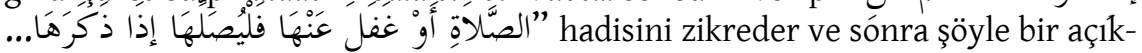
lamada bulunụr: “Bu el-Müsenna'nın naklettiği lafızdır. Saîd'in naklettiği metin

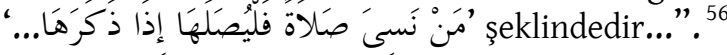

\footnotetext{
Bezzâr, el-Müsned, 13/398.

Müslim, "Mevâkît”, 316; Nesâî, "Mevâkît”, 52.

İbn Hacer, Tehzîbü't-Tehzîb, 4/63-64.

Yatkın, “Hz. Peygamber'in Sünnetinde Namazların Kazası”, 171-172.

Müslim, "Mesâcid”, 313-316.

56 Ebû Bekr Ahmed b. el-Huseyn el-Beyhakî, es-Sünenü'l-kübrâ (Haydarabad: Meclisü Dâirati'lMeârif, 1344), 2/456.
} 


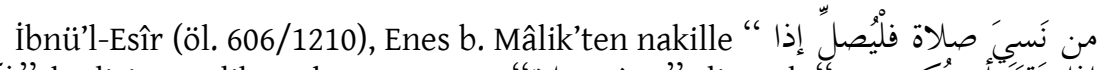

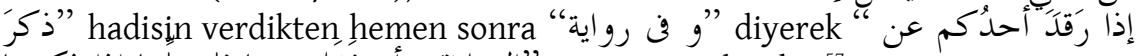
rivayetini zikreder.57" "الصلاة ، أو غفل عنها فليصلها إذا ذكرها

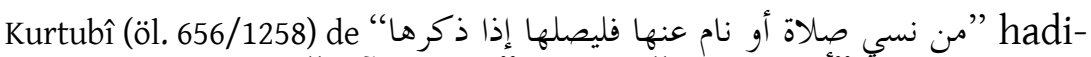

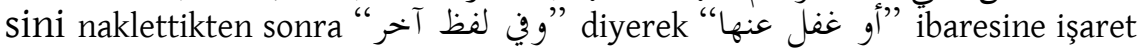
eder. $^{58}$

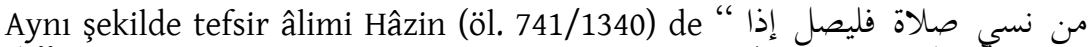

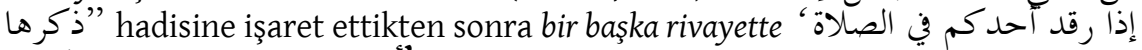
أو غفل عنها فليصلها إذا ذكرها

Mana ile nakil keyfiyetine böyle doğrudan işaret eden müellif örneklerini çoğaltmak mümkündür. Fakat esasen daha önce görüşlerini zikrettiğimiz ve gaflet kelimesini unutmak veya uyumak manasına hamleden diğer bütün müelliflerin, dolaylı yoldan bile olsa, mana ile nakli dikkate aldıkları söylenebilir.

Üzerine yoğunlaştığımız bu mana ile nakil keyfiyeti konusunda en doğru fikri verecek husus, öncelikle Enes'ten Katâde hâricindeki ravilerin, daha sonra da bu konuda diğer sahabîlerin naklettiği rivayetlerin incelenmesi olacaktır. Böylece namazın kazasına imkân veren mazeretlerin neler olduğu ve özellikle de bilinçli terk manasına hamledilebilecek gaflet ibaresinin bunlarda bulunup bulunmadığı tespit edilebilecektir.

\subsubsection{Enes b. Mâlik'in Diğer Ravisi Zührî'den Gelen Rivayetler}

Yaptığımız taramalardan görebildiğimiz kadarıyla Enes'ten bu yönde hadis nakleden tek ravi İbn Şihâb ez-Zührî'dir (öl. 124/741). Zührînnin Enes'ten naklettiği iki metin şu şekildedir:

$$
\begin{aligned}
& \text { من نام عن صلاة أو نسيها فليصلها إذا ذكرها ثم تلا أقم الصلاة لذكري }
\end{aligned}
$$

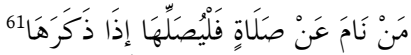

Görüleceği üzere bu rivayetlerde de namazın kazası bağlamında uyuma ve/veya unutma mazeretlerine değinilmiş olup "gaflet" söz konusu edilmemiş-

\footnotetext{
57 Ebü's-Seadât el-Mübârek b. Muhammed İbnü'l-Esîr el-Cezerî, Câmi'u'l-uṣ̂̂l fí ehâdîsisir-Rasûl, thk. Abdülkadir el-Arnaût (Beyrut: Mektebetü'l-Hülvânî, 1390/1971), 5/189.

58 Kurtubî, el-Müfhim, 2/309.

59 Hâzin, Lübâbu't-te'vîl, 3/202.

60 Ebü'l-Kāsım Süleyman b. Ahmed et-Taberânî, el-Mu'cemu'l-evsaț, thk. Târık b. İvazullah (Kahire: Dârü'l-Haremeyn, 1415), 6/182.

61 Bezzâr, el-Müsned, 13/21.
} 
tir. Bu noktada Enes'ten nakleden bu iki ravi arasında yapılan güvenilirlik ve üstünlük sıralamasında, münekkitlerin Zührî̀yi Katâde'nin önüne geçirdiğini ${ }^{62}$ ifade etmemiz gerekir.

\subsubsection{Diğer Sahâbîlerden Gelen Rivayetler}

Namazın kazası konusunda dinin meşru gördüğü sebeplere işaret eden tek rivayet Enes'ten gelmiş değildir. Aksine diğer pek çok sahâbîden de bu bahisle alakalı rivayetler vardir.

Nitekim Ebû Bekre'nin naklettiğine göre Allah Rasûlü şöyle buyurmuştur:

$$
\text { مَنْ نَسِيَ صلاة أَوْ نَامَ عَنهُها فَلْيُصَلِّها إِذَا ذَكَرَهَا } 63
$$

Semure b. Cündeb rivayetinde ise sadece unutmaya işaret vardır:

$$
\text { من نسي صلاة فليصلها إذا ذكرها من الغد للوقت64 }
$$

Ebû Saîd el-Hudrînnin naklettiği rivayette de sadece unutmadan bahsedilir:

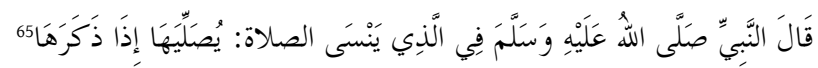

İmrân b. Husayn rivayetinde de vurgu unutmaktan ibarettir:

$$
\text { من نسي صلاة فليصلها إذا ذكرها66 }
$$

Meymûne bnt. Sa'd rivayetinde ise sadece uykudan bahsedilir. Buna göre Meymûne gelip "Yâ Rasûlallah! Güneş doğana veya batana kadar uyuyup namazını kılamayan kişi hakkında bize fetva ver! Bu namazın kefareti nedir?" diye sorunca Allah Rasûlü şöyle buyurur:

$$
\text { إذاذَا ذَكَرَهَا فَلْيُصَلِّها }
$$

Hz. Peygamber sözlerine devamla "Bu kişi namazını kılar ama güzelce kılar, abdestini alır ama güzelce alır. Bu kişinin bundan başka kefareti yoktur” buyurur. $^{67}$

Ebû Katâde'den nakledilen metinden, hadisin Hz. Peygamber'in yanında geçen bir konuşmadan dolayı vârid olduğu anlaşılmaktadır. Buna göre ashabdan bazıları O'nun yanında “(fazla) uyumak sebebiyle kusur işlediklerini zira güneş doğuncaya kadar uyuduklarını" söylediler. Bunun üzerine Cenâb-1 Peygamber

\footnotetext{
62 İbn Hacer, Tehzî̉bü't-Tehzî̉, 2/3; 8/355.

63 Bezzâr, el-Müsned, 9/137; Taberânî, el-Mu'cemu'l-kebîr, 7/235.

64 Bezzâr, el-el-Müsned, 9/137; Taberânî, el-Mu'cemu'l-kebîr, 7/235.

65 Ebû Ya'lâ Ahmed b. Ali el-Mevsılî, el-Müsned, thk. Hüseyin Selîm Esed (Dımaşk: Dârü'l-Me'mûn li’t-Türâs, 1404/1984), 2/407; Taberânî, el-Mu'cemu'l-kebîr, 18/179.

66 Taberânî, el-Mu'cemu'l-kebîr, 18/179.

67 Taberânî, el-Mu'cemu'l-kebîr, 25/35.
} 
"Uyku konusunda (çok uyumak gibi bir) kusur söz konusu değildir. Kusur ancak uyanıklık hali için geçerlidir" uyarısında bulunduktan sonra şöyle buyurur:

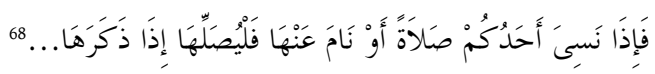

Ebû Cuhayfe rivayetinde de biraz fazla ayrıntıya yer verilir. Bu rivayete göre bir sefer esnasında Hz. Peygamber ve yanındakiler güneş doğana kadar uyumuşlardır. Uyanıp durumu fark edince Allah Rasûlü önce "Sizler (uyku esnasında) ölüler (konumunda) idiniz. Allah ruhlarınızı size geri iade etti (ve uyandınız)." şeklinde bir açıklama yaptıktan sonra şöyle buyurmuştur:

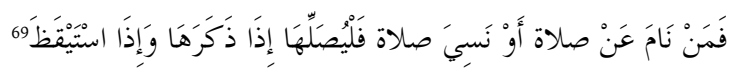

Ebû Hureyre rivayeti de Ebû Cuhayfe metnine benzemekle birlikte ondan daha fazla bilgi içerir. Buna göre Hz. Peygamber Hayber dönüşü gece boyunca yürümüştür. Yorulunca Bilal-i Habeş̂̀yi, sabah namazına kaldırması için nöbetçi olarak bırakıp yatmışlardır. Fakat çok geçmeden Bilal de uyumuştur. Allah Rasûlü ve ashabı ancak yüzlerine vuran güneşin sıcaklığı ile uyanabilmişlerdir. Bunun üzerine Hz. Peygamber abdest almış, Bilal'den kamet getirmesini istemiş ve ashabına sabah namazını kıldırmıştır. Allah Rasûlü namazı bitirince ashabına dönüp şöyle buyurmuştur:

$$
\text { من نسى صلاة فليصلها إذا ذكرها فإن الله تبارك وتعالى قال: أقم الصلاة لذكري720 }
$$

Ebû Hureyre'nin anlattığı olay, daha önce de işarette bulunduğumuz üzere, Zeyd b. Eslem tarafından da aktarılmıştır. Ancak bu rivayette konumuzla alakalı metin şöyle ifade edilmiştir:

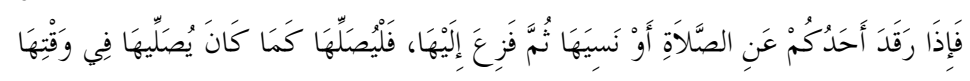

"Sizden biri uyumak veya unutmak suretiyle bir namazı eda edemez sonra da bundan dolayı endişeye kapılırsa vaktinde kılıyormuş gibi kılsın".71

Bunlar dışında Ebû Saîd el-Hudrî̀den gelen bir rivayet daha vardır. Gerçi burada somut bir namaz olarak vitirden bahsedilmektedir. Ancak mazeretler yine ayn olup uyumak ve unutmaktan ibarettir:

68 İbn Mâce, "Salât”, 10; Tirmizî, “Salât”, 18; Nesâî, “Mevâkịt”, 53; Ebü'l-Hasen Ali b. Ömer ed-Dârekutnî, es-Sünen, thk. Abdullah Haşim el-Medenî (Beyrut: Dârü'l-Ma'rife, 1386/1966), 4/109. İbn Ebî Şeybe, el-Mușannef, 1/411; 7/281; Taberânî, el-Mu'cemu'l-kebîr, 22/107.

70 Mâlik b. Enes, el-Muvatța', thk. Muhammed Mustafa el-A'zamî (Suud: Müessesetü Zâyed b. Sultan, 1425/2004), "Vukūtü's-salât", 10; Müslim, "Mesâcid", 55; Ebû Dâvûd, "Salât", 11; İbn Mâce, "Mevâkiit", 10; Nesaî, "Mevâkịt", 52. Ebû Hureyre rivayetleri bazı kaynaklarda ise sadece son cümleden müteşekkil metinle nakledilir: bk. Nesâî, "Mevâkịit", 54; Taberânî, el-Mu'cemu'l-evsaț, 8/349; Dârekutnî, es-Sünen, 4/259.

71 Mâlik, "Vukūtü's-salât", 11. 


$$
\text { من نسي الوتر أو نام عنها فليصلها إذا ذكرها أو إذا أصبح } 72
$$

Bütün bu verilerden anlaşıldığına göre Katâde, gaflet kelimesinin rivayetinde tek kalmıştır. Zira ne Katâde'nin hocası Enes'ten nakleden Zührî rivayetinde ne de diğer sahâbîlerden gelen aynı konuyla alakalı rivayetlerde gaflet ibaresi yer almaz.

Araştırma konumuz olan rivayette geçen "gaflet" ibaresine "kasten terk" manasını yükleyip hadisten "böyle bir eylemin kefareti, onu kaza etmektir" şeklinde bir sonuç çıkarmak, bize göre, dinin namaz konusundaki genel vurgu ve uyarıları ile de çelişir durumdadır.

\subsection{Hadisin Namazın "Kasten" Terkiyle Alakalı Verilerle İlişkisi}

Namazın terki pek çok nassta şiddetle tenkit edilen bir suçtur. Bu bağlamda bazı âyet ve hadislere şöylece işaret edilebilir:

"Onlara rükû edin (namaz kılın) denildiği zaman (itaat edip de) rükûya gitmezler. (Bu suretle Allah'in hükümlerini) yalanlayanların o gün vay haline!"73

"Rabbiniz şöyle buyurdu: Bana dua edin ki size karşllı vereyim. Bana ibâdet etmekten büyüklenip yüz çevirenler, muhakkak ki küçülmüş kimseler olarak cehenneme gireceklerdir." 74

“...Sonra, bunlarin arkasindan namazı zayi eden ve nefislerine uyan bir nesil geldi. (Bunlar yaptıklarının neticesi olarak) Gayyâ çukuruna atılacaklardır."75

Namazı terkin sonuçlarına bazı hadislerde de değinilmiştir:

“Âdemoğlu secde âyetini okuyup secde ederse, şeytan ağlayarak uzaklaşır ve der ki: Vay halime! Âdemoğlu secde etmeye memur oldu ve hemen secde etti. Binaenaleyh cennet onundur. Ben de secde ile emrolundum, ama bundan imtina ettim. Bu sebeple cehennem de benim dir". ${ }^{76}$

"Kim namaza devam ederse kıyamet günü onun için bu namaz nur, delil ve kurtuluş sebebi olur. Kim de namaza devam etmezse, onun nuru, delili ve kurtuluşu yok demektir; o kişi kıyamette Kârûn, Firavun, Hâmân ve Übey b. Halef'le beraber olacaktır". ${ }^{77}$

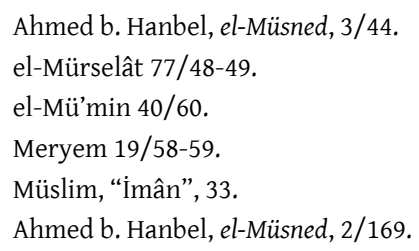


Diğer taraftan din, namazın terki konusunda sadece uyku ve unutmayı mazeret olarak tanımıștır. Ancak uyku ve unutmadan bahseden hadislerin tamamının bu suretle terk edilmiş farz namazlar hakkında, uyaninca veya hatırlayınca kılmaktan başka kefaret yoktur cümlesiyle bitmesi de kayda değer bir husustur. Zira kefaret ancak istemsiz kusurlar için söz konusu edilir. Nitekim Allah Rasûlü namazı ancak güneş doğduktan sonra kıllyor diye şikâyet edilen Safvan b. el-Muattal'a, bir rivayete göre haber gönderip çağırtarak, bunun sebebini sormuş, "benim ve ailemin uykusu çok ağırdır (ثقيل الرأس)" cevabını alınca "o halde uyandı̆̆ın zaman namazını kıl!” buyurmuştur. ${ }^{78}$ Bu hadisten öyle anlaş1lıyor ki Hz. Peygamber, uyku konusunda bile bir gevşeklik olup olmadığını, bunun bir bahane addedilip edilmediğini soruşturma ihtiyacı hissetmektedir.

\section{Sonuç}

Eski dönemlerden beri ilim adamları, uyku ve unutma gibi istem dışı mazeretlere binaen kasten terk edilen farz namazların da kaza edilmesi gerektiği görüşündedir. Bu ilim adamlarının öncelikli delili esasen bir yükümlülüğü vaktinde yerine getirmek nasıl gerekiyorsa, vakti geçtikten sonra yapmak çok daha elzemdir şeklindeki aklî delildir. Fakat bu ilim adamları delil sadedinde bir de hadise atıfta bulunmaktadır. Bu hadise göre Allah Rasûlü "Biriniz uyku veya gaflet sebebiyle namazı terk ederse onu hatırladığı vakit kılsın. Zira Allah 'namazı, beni hatırlamak için kıl' buyurur." demektedir.

Hadisin, kasitlı terke de ihtimâli bulunan gaflet kelimesiyle naklinde Katâde b. Diâme tek kalmıştır. Ayrıca hem bu ravinin hocası Enes b. Mâlik'ten Zührî gibi başka bir ismin aktardığı metinlerde hem de diğer pek çok sahâbîden gelen rivayetlerde kasten terk manasina hamledilebilecek bir kelime yer almaz. Lafız ve muhteva desteğinden mahrum bulunması Katâde'nin gaflet kelimesi ile naklettiği rivayetin şazz ve dolayısıyla zayıf olmasını gerektirir. Fakat Katâde münekkitlerin övgülerine mazhar olmuş sika bir ravidir. Bu da dikkate alındığında bize göre uygun olan, söz konusu rivayette kullanılan gaflet ibaresinin, mana ile nakle tabi tutulduğunu düşünmektir. Zira Katâde'den gelen ve namazın kazasına sebep olabilecek hususların sayıldığı rivayetler bir araya toplandığında onun üç ravisinin gaflete işaret eden metinlerine karşılık altı öğrencisinin uyuma ve unutmadan bir veya ikisine yer veren kelimeler kullandığı görülür. Hem bunlar hem diğer sahabîlerden gelen aynı konudaki rivayetler hem de hadisten bir şekilde bahseden ulemanın genelinin tercihleri göz önüne alındığında Katâde'nin, söz konusu rivayette geçen gaflet ibaresini unutma manasında kullandığı söylenebilir.

78 Hadisin değişik rivayetleri için bk. Ahmed b. Hanbel, el-Müsned, 3/80; Ebû Dâvûd, "Savm", 74 (2458); Ebû Cafer Ahmed b. Muhammed et-Tahâvî, Şerhu Müşkili'l-Âŝar, thk. Şuayb el-Arnaût (Beyrut: Müessesetü'r-Risâle, 1408/1987), 5/286; İbn Hibbân, eṣ-Sahị̂h, 4/354. 
Bize göre bu tercih, gaflet ibaresine yer veren bütün hadislerin sonunda yer alan bunun telafisi, söz konusu namazı hatırlayınca (إذا ذكرها) kılmaktır cümlesiyle de uyum arz edecektir. Zira hatırlama durumu, unutma ile ilişkili olup kasten terk hakkında kullanılması öncelikli bir tercih değildir. Gerçi bu noktada bu son cümleyi kasten kılmayan kişi bu namazı bir süre unutur. Daha sonra aklına geldiğinde onu kılsin manasına hamletme ihtimali de akla gelebilir. Ancak bu ihtimal, dinin namaz konusundaki genel vurgu, uyarı ve kılmayanlara yönelik şiddetli tenkitleri ile çelişir durumdadır. Bu nasları dikkate alındığında dinin, namazın kasten terkini bir seçenek olarak ele almadığı, kanaatimizce, rahatlıkla söylenebilir.

Bütün bu verilerden hareketle denilebilir ki "Biriniz uyku veya gaflet sebebiyle namazı terk ederse onu hatırladığı vakit kılsın" hadisinin, kasten terk edilen namazlar da kaza edilmelidir görüşü için delil addedilmesi yanlış olacaktır. Daha doğru görünen, söz konusu kelimenin unutma manasına hamlidir. 


\section{Kaynakça}

Ahmed b. Hanbel, Ebû Abdillâh Ahmed b. Muhammed b. Hanbel eş-Şeybânî. elMüsned. İstanbul: Çağrı Yayınları, 1982.

Abdullah b. Ahmed b. Hanbel. Mesâ’ilü Ahmed b. Hanbel. thk. Züheyr eș-Şâvîş. Beyrut: el-Mektebü'l-İslâmî, 1401/1981.

Apaydın, Hacı Yunus. “Gaflet”. Türkiye Diyanet Vakfi İslâm Ansiklopedisi. 13/284285. İstanbul: TDV Yayınları, 1996.

Aynî, Ebu Muhammed Bedrüddîn Mahmûd b. Ahmed. Nühabü’l-efkâr fî tenkîhi mebâni'l-ahbâr fi şerḥi Me'âni'l-Âsâr. thk. Ebû Temîm Yâsir b. İbrahim. 19 Cilt. Katar: Vüzâratü'l-Evkāf, 1429/2008.

Beyhakî, Ebû Bekr Ahmed b. el-Huseyn. el-Hilâfiyât beyne'l-imâmeyn eş-Şâfi î ve Eb̂̀ Hanîfe ve așhâbih. thk. Mahmûd b. Abdilfettâh. 8 Cilt. Kahire: er-Ravda li'nNeşr ve’t-Tevzî, 1436/2015.

Beyhakî, Ebû Bekr Ahmed b. el-Huseyn. es-Sünenü'l-kübrâ. 10 Cilt. Haydarabad: Meclisü Dâirati'l-Me'ârif, 1344.

Bezzâr, Ebû Bekr Ahmed b. Amr el-Atekî. el-Müsned. thk. Âdil b. Sa'd. 18 Cilt. Medine: Mektebetü'l-Ulûm ve'l-Hikem, 1988-2009.

Buhârî, Ebû Abdillâh Muhammed b. İsmâîl. el-Câmi'u'ș-Ṣahîh. thk. Mustafa Dîb elBuḡā. Beyrut: Dâru İbn Kesîr, 1407/1987.

Cürcânî, Ali b. Muhammed es-Seyyid eş-Şerîf el-Cürcânî. et-Ta'rîfât. thk. Komisyon. Beyrut: Dâru'l-Kütübi'l-İlmiyye, 1403/1983.

Dârekutnî, Ebü'l-Hasen Ali b. Ömer. es-Sünen. thk. Abdullah Hâşim el-Medenî. 4 Cilt. Beyrut: Dâru'l-Marife, 1386/1966.

Dârimî, Ebû Abdillâh Abdullah b. Abdirrahmân. el-Müsned. thk. Hüseyin Selim Esed. 4 Cilt. Suud: Dâru'l-Muğnî, 1412/2000.

Ebû Avâne Ya'kūb b. İshâk en-Nîsâbûrî. el-Müstahrec. thk. Eymen b. Ârif ed-D1maşkî. 5 Cilt. Beyrut: Dâru'l-Ma'rife, 1419/1998.

Ebû Dâvûd, Süleyman b. Eş‘as es-Sicistânî. es-Sünen. Beyrut: Dâru'l-Kütübi'lArabî, ts.

Ebû Ya'lâ, Ahmed b. Ali el-Mevsılî. el-Müsned. thk. Hüseyin Selim Esed. 13 Cilt. Dimaşk: Dâru'l-Me'mûn li’t-Türâs, 1404/1984.

Ebû Ya'lâ, Muhammed b. el-Huseyn el-Ferrâ. et-Ta'lîku'l-kebîr fi'l-mesâ'ili'l-hilâfiye beyne'l-e'imme. thk. Muhammed b. Fahd. 4 Cilt. Dımaşk: Dâru'n-Nevâdir, $1435 / 2014$. 
Feyyûmî, Ahmed b. Muhammed. el-Miṣbâhu'l-münîr. 2 Cilt. Beyrut: el-Mektebetü'l-illmiyye, ts.

Hâzin, Ebü'l-Hasen Alâüddin Ali b. Muhammed. Lübâbü't-te'vîl fî me âni't-tenzîl. thk. Muhammed Ali Şahin. 4 Cilt. Beyrut: Dâru'l-Kütübi'l-İlmiyye, 1415.

İbn Ebî Şeybe, Ebû Bekr Abdullah b. Muhammed el-Absî. el-Muṣannef. thk. Kemal Yusuf el-Hût. 7 Cilt. Riyad: Mektebetü'r-Rüşd, 1409.

İbn Hacer, Ebü'l-Fazl Ahmed b. Ali el-Askalânî. Tehzîbü't-Tehzî̂b. 12 Cilt. Hindistan: Matbaatü Dâirati'l-Me‘ârif, 13268.

İbn Hacer el-Heytemî, Ebü'l-Abbâs Ahmed b. Muhammed b. Hacer. el-Minhâcü'lkavîm. Beyrut: Dâru'l-Kütübi'l-İlmiyye, 1420/2000.

İbn Harrât, Ebû Muhammed Abdülhak b. Abdirrahmân el-Endelusî. el-Aḥkâmü'şşer'iyyeti'l-kübrâ. thk. Hüseyin b. Ukkāşe. 5 Cilt. Riyad: Mektebetü'r-Rüşd, $1422 / 2001$.

İbn Mâce, Ebû Abdillâh Muhammed b. Yezîd el-Kazvînî. es-Sünen, thk. Muhammed Fuâd Abdülbâkī. Beyrut: Dâru'l-Fikr, ts.

İbn Hibbân, Ebû Hatim Muhammed b. Hibbân el-Büstî. eș-Ṣahîh. thk. Şuayb elArnaût. 18 Cilt. Beyrut: Müessesetü'r-Risâle, 1414/1993.

İbn Kudâme, Ebû Muhammed Abdullah b. Ahmed el-Makdisî. el-Mugnnî. 10 Cilt, Kahire: Mektebetü Kâhire, 1388/1968.

İbn Teymiyye, Ebü'l-Abbâs Ahmed b. Abdilhalîm el-Harrânî. Şerḥu'l-cumde. thk. Hâlid b. Ali. Riyad: Dâru'l-Âsime, 1418/1997.

İbn Huzeyme, Ebû Bekr Muhammed b. İshâk b. Huzeyme en-Nîsâbûrî. eș-Șahîh. thk. Muhammed Mustafa el-A'zamî. 2 Cilt. Beyrut: el-Mektebü'l-İslâmî, $1424 / 2003$.

İbn Sa'd, Ebû Abdillâh Muhammed b. Sa'd b. Menî‘ el-Bağdâdî. eț-Ṭabakātü'lkübrâ. thk. Muhammed Abdülkādir Atâ. 8 Cilt. Beyrut: Dârü'l-Kütübi'l-İlmiyye, 1410/1990.

İbnü'l-Esîr, Ebü's-Seadât el-Mübârek b. Muhammed el-Cezerî. Câmi'u'l-ușûl fi ehâdîsisir-Rasûl. thk. Abdülkādir el-Arnaût. 12 Cilt. Beyrut: Mektebetü'l-Hülvânî, 1390/1971.

İbnü's-Salâh, Ebû Amr Osman b. Abdirrahmân eş-Şehrezûrî. 'Ulûmü'l-ḥadîs. thk. Nureddin Itr. Suriye: Dâru'l-Fikr, 1406/1986.

İbrahim Mustafa vd. el-Mu'cemü'l-vasiț. 2 Cilt. Beyrut: Dâru'd-Davet, ts.

Karâfî, Ebü'l-Abbâs Şihâbüddîn Ahmed b. İdrîs b. Abdirrahmân. ez-Zahîra. thk. Muhammed Hacî. 14 Cilt. Beyrut: Dâru'l-Garb, 1994. 
Kurtubî, Ebü'l-Abbâs Ahmed b. Ömer. el-Müfhim limâ eşkele min telhîși kitâbi Müslim. thk. Muhyiddin Dîb Misto. 7 Cilt. Dımaşk: Dâru İbn Kesîr, 1417/1996.

Mâlik b. Enes, Ebû Abdillâh Mâlik b. Enes el-Asbahî. el-Muvațta’ thk. Muhammed Mustafa el-A'zamî. 8 Cilt. Abu Dabi: Müessesetü Zâyed b. Sultan, 1425/2004.

Muhammed Fuâd Abdülbâkī. el-Mu'cemü'l-müfehres li elfâzị'l-Kurâani'l-kerîm. Kahire: Matba'atü Dâri'l-Kütübi'l-Misriyye, 1364/1945.

Mübârekpûrî, Ebü'l-Hasen Ubeydullah b. Muhammed. Mir'âtü'l-mefâtîh şerhu Mişkâti'l-meșâbîh. 9 Cilt. Hindistan: İdâretü'l-Buhûsü'l-İlmiyye, 1404/1984.

Müslim b. el-Haccâc, Ebü'l-Hasen el-Kuşeyrî. el-Câmi'u'ṣ-Ṣahîh. thk. Muhammed Fuâd Abdülbâkī. 4 Cilt. Beyrut: Dâru İhyâi't-Türâsi'l-Arabî, 1954.

Nesâî, Ebû Abdillâh Ahmed b. Şuayb. es-Sünen. thk. Abdülfettâh Ebû Gudde. 8 Cilt. Haleb: Mektebetü'l-Matbûâti'l-İslâmiyye, 1406/1986.

Polat, Selahaddin. “Gaflet”. Türkiye Diyanet Vakfi İslâm Ansiklopedisi. 13/285-286. İstanbul: TDV Yayınları, 1996.

Râğib el-İsfehânî, Ebü'l-Kāsım el-Huseyn b. Muhammed. el-Müfredât fi garî̉bi'lKur'ān. thk. Safvân Adnan ed-Dâvûdî. Dımaşk: Dârü'l-Kalem, 1412.

Sââtî, Ahmed b. Abdirrahmân. el-Fethü'r-rabbânî li-tertîbi'l-Müsnedi'l-İmâm Aḥmed b. Hanbel eş-Şeybânî. 24 Cilt. Beyrut: Dâru İhyâi't-Türâsi'l-Arabî, ts.

Sübkî, Mahmûd Muhammed Hattâb. el-Menhelü'l-'azbi'l-mevrûd şerhu Süneni'lİmâm Ebî Dâvûd. thk. Emin Mahmûd Muhammed. 6 Cilt. Kahire: Matbaatu'lİstikâme, 1351-1353.

Şinkitî, Muhammed el-Emîn b. Muhammed el-Muhtâr. Edvấü'l-beyân fi ị̂âhị'lKur'āni bi'l-Kur'ān. 9 Cilt. Beyrut: Dârü'l-Fikr, 1415.

Şevkânî, Muhammed b. Ali. Neylü'l-evțâr. thk. İsâmuddin es-Sabâbitî. 8 Cilt. Mısır: Dârü'l-Hadîs, 1413/1993.

Taberânî, Ebü'l-Kāsım Süleyman b. Ahmed. el-Mu'cemü'l-evsaț. thk. Târık b. İvzullah. 10 Cilt. Kahire: Dârü'l-Haremeyn, 1415.

Taberânî, Ebü'l-Kāsım Süleyman b. Ahmed. el-Mu'cemü'l-kebîr. thk. Hamdî b. Abdilmecîd. 20 Cilt. Musul: Mektebetü'l-Ulûm ve'l-Hikem, 1404/1983.

Tahâvî, Ebû Cafer Ahmed b. Muhammed. Şerḥu Müşkili'l-Âŝâr. thk. Şuayb el-Arnaût. 15 Cilt. Beyrut: Müessesetü'r-Risâle, 1408/1987.

Tîbî, Şerefüddin el-Huseyn b. Abdillâh. el-Kâşif 'an hakkā'iki's-sünen. thk. Abdülhamîd Hindâvî. 13 Cilt. Riyad: Mektebetü Nizar Mustafa el-Bâz, 1417/1997.

Tirmizî, Ebû Îsâ Muhammed b. Îsâ b. Sevre. es-Sünen. thk. Ahmed Muhammed Şakir. 5 Cilt. Beyrut: Dâru İhyai't-Türâsi'l-Arabî, ts. 
Uludağ, Süleyman. “Gaflet”. Türkiye Diyanet Vakfi İslâm Ansiklopedisi. 13/283-284. İstanbul: TDV Yayınları, 1996.

Vellevî, Muhammed b. Ali el-İsyûbî. Zehîratü'l-‘ukbâfîşerhi'l-Müctebâ. 40 Cilt. Beyrut: Dârü'l-Me'âric, 1416/1996.

Yatkın, Nihat. “Hz. Peygamber'in Sünnetinde Namazların Kazası”. EKEV Akademi Dergisi 3/1 (2001), 163-177.

Zeylaî, Fahruddîn Osman b. Ali. Tebyînu'l-hakā’’k şerḥu Kenzi'd-dekā̄ik. 6 Cilt. Kahire: Dâru'l-Kütübi'l-İslamî, 1313.

Zuhaylî, Vehbe b. Mustafa. et-Tefsîru'l-münîr fi'l-‘akỉde ve'ş-şerî‘a ve'l-menhec. 30 Cilt. Dımaşk: Dârü'l-Fikr, 1418. 


\section{A Hadith and Its Assessment Proves That Intentionally Abandoned Prayer Could Be Performed After Its Own Time}

\section{Extended Summary}

Prayer is the most mentioned worship in the Quran and hadiths. In these sources, it is also seen that various details related to prayer also offer solutions to problems that may prevent it from acting on time. From this point of view, it can be said that the religion does not accept any excuses except for a few issues about excuses that will prevent the performance of an obligatory (fard) prayer on time.

There is an alliance among the scholars that a Muslim can perform later the prayer that he could not perform on time due to sleep or forget. As a matter of fact, according to the Prophet's statement, this situation has no other atonement. However, scholars disagreed about whether a person would perform later a prayer that he didn't perform it in time deliberately due to reasons such as laziness and preoccupation. This dispute appears to be largely shaped by the relevance between prayer and the faith. All of the scholars who believe that prayers that are deliberately abandoned in addition to sleep and forgetting should be perform later point to a certain hadith as evidence of these views. According to this hadith, the Messenger of Allah states: "If one of you leaves the prayer due to sleep or heedlessness, do it when remember. Because Allah says "pray for me to remember me."

When the narrations of the authors who reported the hadith are compared, it is seen that it is sound in terms of isnād. The texts narrated by these authors, on the other hand, differ from each other in meaning and narration. The common point of these texts is that prayers that are neglected due to sleep and heedlessness should be performed after remembering. The word of "remembering" is important in determining the evidence of the hadith. Because the act of remembering can also be associated with sleep, forgetting and deliberate abandonment. However, it is seen that some scholars refer to the expression of heedlessness in the hadith as "deliberate abandonment". According to them, it is possible that the word heedlessness mentioned in the hadith means "to comply with one's own desires and behave towards them." Some scholars, on the other hand, understand it as "forgetting." According to the third view, this key word means "sleep".

As it is understood from these data, it is possible that the word of heedlessness may be understood as intentional behaviors such as deliberate abandonment as well as unintentional actions such as sleep and forgetting. However, according to this last preference, religion will refer to the deliberate abandonment of an obligatory prayer and show its compensation. Such a meaning causes a very 
dangerous result for both society and individual. Because human beings tend to be easy and comfortable by nature. If religion considers the deliberate abandonment of an obligatory prayer as a possibility, it is likely that a person will consider it as a license. Therefore, before reaching such a serious conclusion, it will be of great benefit to examine other data about sleeping, forgetting and especially deliberate abandonment of an obligatory prayer and reveal the basic approach in them.

In the majority of hadiths that mention the compensation of prayers, the excuses that will lead to this are associated with sleeping and / or forgetting. The most striking among these are the narrations that came with the chain of "Anas b. Mālik $\rightarrow$ Qatāda" as in the hadith, which is our subject of research, but do not include the word heedlessness contrary to it. Another important point is that these narrations, which do not include the word heedlessness, are much more common than those who give. This situation makes us think that all the narrations that include the words forgetting and / or sleeping and heedlessness and that came with the chain of "Anas $\rightarrow$ Qatāda" essentially point to the same event, but suffer from differences in wording arising from the meaning and the narration. According to this, when Qatāda (d. 117/735) narrated the hadith in question to his students, he expressed the key word, the excuse or reason that could cause the accident of the prayer, with different words. In this context, we should point out that Qatāda's student, who is considered the most reliable among his students, narrates the hadith with the words forgetting and sleeping. There is no word of negligence in the narrations from al-Zuhrī (d. 124/741), another narrator of Anas. When the narrations of other Companions pointing to the legitimate reasons of the prayer are examined, there are only one or both signs of forgetting and sleeping. Apart from these traditions, the general emphasis and warnings of the religion about prayer are in contradiction with an act such as deliberate abandonment. For, in the verses and hadiths that mention this issue, the great penalties that will be inflicted on deliberate abandonment of prayer are indicated.

Based on all these data, it can be said that It is more appropriate to take the word heedlessness as forgetting in the hadith, "If one of you leaves the prayer due to sleep or heedlessness, do it when remember." As such, it would be wrong to provide evidence of the hadith for the claim prayers that are deliberately abandoned must also be compensated later also fail.

Keyword: Hadith, Prayer, To Abandon Prayer, To Perform Prayer After its Time, Sleep and Forget, To Abandone Deliberately. 